\title{
EUROPEAN UNIVERSITY INSTITUTE (EUI) INSTITUT UNIVERSITAIRE EUROPEEN (IUE)
}

\author{
Badia Fiesolana \\ Via dei Roccettini 5 \\ 50016 San Domenico di Fiesole (Italy) \\ 1976 \\ Tel: 055/50921 \\ Fax: 055/599877 \\ Telex: 571528 iue i \\ Cables: univeur \\ President: Emile Noël
}

Secretary-General: Marcello Buzzonetti

The EUI takes in research students from all countries of the European Community, for periods of one to three years. Its mission is: to provide a training in research for young European graduates intending to take the Institute'sdoctorate after three years; to provide additional training for students registered for a doctorate in their own country, who wish to defend a thesis there after a stay of one or two years at the Institute; to develop joint doctoral programmes with European universities doing active reseach in the same fields as the Institute.

Law graduates may also take the one-year Master's degree in Comparative, European and International Law, at a level comparable with a British LL.M. Similarly, in the Economics Department, it is possible to take a one-year Master's Degree in Economics.

Principal publications: A complete list of the publications of members of the Institute may be obtained from the address given above.

L'Institut universitaire européen (IUE) accueille, pour des périodes allant de un à trois ans, des étudiants de tous les pays de la Commnauté européenne effectuant des travaux de recherche. Il a pour mission: d'offrir une formation dans le domaine de la recherche aux jeunes diplômés souhaitant préparer une thèse de doctorat de l'Institut après trois années d'études; d'assurer une formation complémentaire aux étudiants inscrits à un doctorat dans leur propre pays et qui désirent y soutenir une thèse après une ou deux années d'études à l' Institut; de multiplier le nombre des programmes de doctorat conjoints avec les universités européennes menant activement des travaux de recherche dans les mêmes domaines que l'Institut. Les diplômés en droit peuvent également s'inscrire à une année supplémentaire conduisant au "Master's degree" en droit comparatif, européen et international, à un niveau d'études comparable au LL.M. britannique. De même, il est possible de s'inscrire à une année au Département des Sciences économiques menant au "Master's degree" en économie.

Publications principales: Une liste complète des publications de membres de l'Institut peut être obtenue à l'adresse mentionnée ci-dessus. 